\title{
Spatial Variability of Reinforcement Provided by Juvenile Root Systems of Black Locust and Black Poplar
}

\author{
Tymoteusz Zydroń ${ }^{1 *}$, Andrzej Gruchot ${ }^{1}$, Marcin Kluba² \\ 'Department of Hydraulic Engineering and Geotechnics, Faculty of Environmental Engineering \\ and Land Surveying, University of Agriculture in Kraków, Kraków, Poland \\ ${ }^{2}$ Graduate of the University of Agriculture in Krakow, Faculty of Environmental Engineering \\ and Land Surveying, Poland
}

Received: 24 April 2018

Accepted: 22 September 2018

\begin{abstract}
Our work aimed to determine the spatial distribution of the root cohesion of the roots of 8 -year-old black locust and black poplar trees. The scope of our research and analyses included determining characteristics of root systems of the studied tree species by profiling the walls of a trench with a width and a depth of $1.0 \mathrm{~m}$ at a distance of 0.5 and $1.0 \mathrm{~m}$ from the trunks. Laboratory tests comprised determining the tensile strength of the selected root classes. A modified Schwarz model (RDM) was used to describe the horizontal distribution of roots in the soil. The increase in shear strength of the root-reinforced soil was determined by a strain bundle model in which the value of the force mobilized by the roots is described by the Weibull survival function (RBMw). The results of the root system measurements have shown that the black locust is characterized by a greater number of roots, while the roots of black poplar are thicker, which makes the relative surface of its roots larger. Calculations of root cohesion using the modified bundle model, taking into account the root system displacement, showed that the maximum value for the black locust was 9.4 and $6.4 \mathrm{kPa}$, and for the black poplar 6.4 and $6.2 \mathrm{kPa}$ respectively at a distance of 0.5 and $1.0 \mathrm{~m}$ from the trunk. It was also shown that the optimal spacing of the trees of these species, necessary to achieve effective reinforcement of the soil, was approximately $4 \mathrm{~m}$.
\end{abstract}

Keywords: soil reinforcement, root distribution, root bundle model, Weibull survival function

\section{Introduction}

The impact of tree vegetation on the subsoil is complex and its influence on slope stability can be both

*e-mail: tymoteusz.zydron@urk.edu.pl positive and negative. Vegetation, for life processes, needs water, which is retained during precipitation within the crown, and retrieved from soil through the root system. These processes reduce the soil moisture content and pore water pressure [1-3], and as a consequence an increase in shear strength occurs, which is beneficial from a geotechnical point of view. In an extreme case, excessive intensity of water transpiration 
by plants leads to cracks in the ground, which in turn may serve as privileged paths for rainwater infiltration. The weight of trees also constitutes an additional load on the soil, which, depending on its location on the slope, can reduce or increase its stability [4]. The root systems of trees have a positive effect on the stability of the slope. During the deformation of the soil, the roots get deformed, which causes friction between the soil and the root bundle and mobilisation of their tensile strength. As a result of this phenomenon, the shear strength of the soil is increased, which is identified with the increase in apparent cohesion, and which can be described by the formula:

$$
\tau_{f}=(\sigma-u) \cdot \tan \varphi^{\prime}+c^{\prime}+c_{r}
$$

...where $\tau_{\mathrm{f}}$ - shear strength of the soil, $\sigma$ - normal stress, $\mathrm{u}$ - pore water pressure, $\varphi^{\prime}$ - effective angle of internal friction of the soil, c' - soil cohesion, and $c_{r}$ - increase in soil shear strength due to the presence of roots in the soil (root cohesion).

Most often, the soil reinforcement effect has the character of lateral reinforcement [5-9], because the roots rarely reach below the slip plane, and more often they cut it in the surface part of the ground profile. The effect of soil reinforcement is related to the number and dimensions of roots and their orientation relative to the slip plane and tensile strength, which can be described by $[10-11]$ :

$$
c_{r}=k^{\prime} \cdot \sum_{i=1}^{N}\left(T_{r i} \cdot R A R_{i}\right)
$$

...where $T_{r i}$ - tensile strength of a root, $\mathrm{RAR}_{\mathrm{i}}$ - relative area of the root with respect to the soil surface area (root area ratio), and k' - coefficient of orientation of roots in relation to the slip plane (usually taken from the range of 1.0-1.3).

The above equation constitutes the basic computational model for determining the effect of root systems on soil shear strength (Wu-Waldron model), in which the $T_{r i}$ value corresponds to the maximum breaking strength.

The root tensile strength is a characteristic feature of individual plant species, and the density of their root system depends primarily on their age, habitat conditions and changes with distance from the trunk. Therefore, in order to determine the impact of tree root systems on the shear strength of the soil, it seems relevant to determine the number of roots in the horizontal layout [6-7, 12-13]. On the other hand, the root tensile strength of the plant is largely dependent on their diameter, but it is also characterized by very high variability, which results in a relatively high uncertainty of the impact of this parameter, which can be reduced by using statistical analysis tools to describe it [14].

The species of trees found in the climatic conditions of Poland and characterized by fast growth include black locust and black poplar. These species are also characterized by a well-developed root system that can be used in the application of bioengineering procedures related to, for example, biological reclamation of landfills [15] or biological reinforcement of earth engineering structures [9, 16-17]. From the point of view of designing this type of treatment, the initial period of operation of a structure is of great importance when there is a rapid growth of vegetation and the associated process of development of the root system.

Our work tried to determine the spatial distribution of the increase in soil shear strength resulting from its reinforcement with the roots of black locust and black poplar trees. The scope of our research and analyses included determining characteristics of root systems of the studied tree species, tensile strength of the selected root classes as well as calibration of the parameters of the root distribution model in the soil.

\section{Materials and Methods}

Our study was conducted for the species of trees growing on the plantation of energy crops of the Faculty of Production and Power Engineering of the University of Agriculture in Krakow (N 504'54, E 1952'2). The study area is situated on a flat (planar) terrain in the valley of the Rudawa River. The analyzed tree species were planted in 2009 and from this period no fertilization works were done. The age of studied trees, determined using increment borer, was estimated at 8 years. The diameter of the trees at the root collar of the black locust was in the range 0.09 to $0.12 \mathrm{~m}$, and of the black poplar from 0.07 to $0.12 \mathrm{~m}$. The substrate was a layer of an anthropogenic mineral soil with a thickness of about $0.7 \mathrm{~m}$, which in terms of grain size was classified as sand with silt or sand [18]. A layer of sand with a dark-coloured silk lay beneath the layer of made ground. In this layer, the remains of plants from the horsetail family were found, and near the plantation there was a depression in the area in which water stagnated, which may indicate that in the past this area was waterlogged.

Grain-sized distribution of soils was determined by a combined method, i.e., sieve and areometric analyses, according to the recommendation of PN-EN ISO 17892-4:2009 [19]. Physicochemical properties of soils were determined on dried samples sifted through a sieve with a $2 \mathrm{~mm}$ mesh. $\mathrm{pH}$ of soils was determined in distilled water and $1 \mathrm{~mol} \mathrm{KCl}$ by the potentiometric method; the total organic carbon (TOC) and total nitrogen $(\mathrm{N})$ content in the soils were determined using an Elementar Vario MAX cube CNS analyzer, and the cation exchange capacity (CEC) of soil [21-22]. Total element concentration $(\mathrm{K}, \mathrm{P})$ in the soils was assessed after hot digestion in a mixture of $\mathrm{HNO}_{3}$ and $\mathrm{HClO}_{3}$ $(3: 2 \mathrm{v} / \mathrm{v})$ acids (suprapure, MERCK). Element concentrations were analyzed using the ICP-OES method (inductively coupled plasma atomic emission spectroscopy) on an Optima 7300 DV (Perkin-Elmer) 
Table 1. Soil characteristics.

\begin{tabular}{|c|c|c|c|}
\hline \multirow{2}{*}{ Parameter } & \multicolumn{3}{|c|}{ Depth } \\
\hline & $0.0-0.30$ & $0.30-0.80$ & $0.75-1.00$ \\
\hline \multicolumn{4}{|c|}{ Grain-size distribution } \\
\hline \multicolumn{4}{|l|}{ Fraction content $[\%]$ : } \\
\hline Sand $(2-0.063 \mathrm{~mm})$ & 72.4 & 76.4 & 67.7 \\
\hline Silt (0.063-0.002 mm) & 27.0 & 23.3 & 32.0 \\
\hline Clay $(<0.063 \mathrm{~mm})$ & 0.6 & 0.3 & 0.3 \\
\hline Name of the soil acc. to [20] & siMSa & siMSa & siMSa \\
\hline \multicolumn{4}{|c|}{ Physicochemical properties } \\
\hline $\mathrm{pH}_{\mathrm{H} 2 \mathrm{O}}[-]$ & 6.78 & 6.96 & 6.83 \\
\hline $\mathrm{pH}_{\mathrm{KCl}}[-]$ & 6.29 & 6.43 & 6.53 \\
\hline Cation exchange capacity (CEC) $[\mathrm{mmol} / 100 \mathrm{~g}]$ & 13.92 & 10.03 & 19.00 \\
\hline Total organic content (TOC) [\%] & 0.53 & 0.17 & 1.08 \\
\hline $\mathrm{CaCO}_{3}$ content $[\%]$ & 0.64 & 0.75 & 0.13 \\
\hline $\mathrm{N}$ content [g.kg-1 d.m.] & 0.49 & 0.2 & 1.01 \\
\hline P content $\left[\mathrm{g} \cdot \mathrm{kg}^{-1}\right.$ d.m. $]$ & 0.67 & 0.41 & 0.53 \\
\hline $\mathrm{K}$ content $\left[\mathrm{g} \cdot \mathrm{kg}^{-1}\right.$ d.m. $]$ & 0.23 & 0.09 & 0.4 \\
\hline
\end{tabular}

[21]. Each sample of the soil material was analysed in two replications. If the results of those replications differed from one another by more than $\pm 5 \%$, another two analyses of that sample were conducted. Soil properties are presented in Table 1.

Apart from the studied tree species, the test area was also covered by herbaceous species. In the vicinity of black poplar, there were: Canadian goldenrod (Solidago canadensis L.), giant goldenrod (Solidago gigantea), tancy (Tanacetum vulgare L.), velvet grass (Holcus lanatus L.), Canada bluegrass (Poa compressa L.), goutweed (Aegopodium podagraria L.), fowl bluegrass (Poa palustris L.), annual fleabane (Erigeron annuus (L.)), common nettle (Urtica dioica L.), common horsetail (Equisetum arvense), European blackberry (Rubus L.), bindweed (Convolvulus arvensis L.), mouse-ear chickweed (Cerastium holosteoides), wild carrot (Daucus carota L.), cow vetch (Vicia cracca L.), common mugwort (Artemisia vulgaris L.), creeping buttercup (Ranunculus repens L.), field horsetail (Equisetum arvense L.), Torilis japonica (Torilis japonica) and common windgrass (Apera spica-venti). In the case of black locust, ground elder (Aegopodium podagraria L.) was a dominant species, but annual fleabane (Erigeron annuus L.), common nettle (Urtica dioica L.), erect hedgeparsley (Torilis japonica), greater celandine (Chelidonium majus L.), ground-ivy (Glechoma hederacea L.), white nettle (Lamium album L.), germander speedwell (Veronica chamaedrys), Carex brizoides L., Galium and Potentilla species, thicket creeper (Parthenocissus inserta), and meadow fescue (Festuca pratensis Huds.).
As a main part of the research, measurements were made of the number and diameter of the roots of the studied tree species in research excavations of a depth and width of $1.0 \mathrm{~m}$, at a distance of 0.5 and $1.0 \mathrm{~m}$ from the tree trunks. After making each of the trenches, the wall in the immediate vicinity of the tree was burrowed to a depth of a few centimetres in order to expose the roots, and then $10 \mathrm{~cm}$ thick layers of soil were separated. Plants of herbaceous vegetation also appeared on the plots, and the roots of each species were isolated on the basis of colour and smell. For four selected trees of each species, 8 trenches were made: 4 at each of both distances from the trunk. Based on the measurements we performed calibration of the parameters of the root distribution model (RDM) developed by Schwarz et al. [7] and modified by Giadrossich et al. [13]. In this model, it is assumed that the root system develops symmetrically around the tree, and that root density is determined according to the formula:

$$
N_{i, t}(d, D B H)=D_{f r} \cdot \frac{\ln \left(1+\phi_{\max }\right)-\ln \left(1+\phi_{i}\right)}{\ln \left(1+\phi_{\max }\right)} \cdot\left(\frac{\phi_{i}}{\phi_{0}}\right)^{v}
$$

...where $\mathrm{N}_{\mathrm{i}, \mathrm{t}}$ - number of roots with assumed class of diameters, $\mathrm{d}$ - distance from the trunk, DBH - diameter at the base of the root collar (or at breast height), $\phi_{0}-$ reference root diameter $\left(\phi_{0}=1 \mathrm{~mm}\right), \phi_{\max }-$ maximum root diameter at the distance $\mathrm{d}, \phi_{\mathrm{i}}-$ mean root diameter in a given class, diameter classes were assumed every 1 $\mathrm{mm}, \mathrm{v}$ - empirical exponent, and $\mathrm{D}_{\mathrm{fr}}$ - fine roots density, calculated from the formula: 


$$
D_{f r}=\left(\frac{\mu \cdot D B H^{2} \cdot \pi}{8 \cdot d_{\max } \cdot \pi \cdot d}\right) \cdot\left(\frac{d_{\max }-d}{d_{\max }}\right)
$$

...where $\mu$ - pipe-theory coefficient and $d_{\max }-$ the maximum range of the root system determined from the formula:

$$
\begin{gathered}
d_{\max }(D B H)=a_{0} \cdot D B H \\
\phi_{\max }(D B H)=\frac{d_{\max }-d}{\eta}
\end{gathered}
$$

...where $\mathrm{a}_{0}-$ scaling factor and $\eta-$ dimensionless self similarity coefficient.

Calibration of the model consists of the estimation of the parameters $a_{0}, \eta, \gamma$ and $\mu$. First, the parameters $a_{0}$ and $\eta$ were determined in accordance with the procedure described in the work of Vergani et al. [23], and then the other two parameters were estimated using the non-linear regression method in the Statistica 8.0 program. These calculations were made for over a dozen pairs of $a_{0}$ and $\eta$ values, and those values for which the smallest total error value (EV) was obtained were considered to be appropriate:

$$
E V=\frac{\left(\sum_{i=1}^{N} N_{i, m}-\sum_{i=1}^{N} N_{i, t}\right)}{\sum_{i=1}^{N} N_{i, m}} \cdot 100
$$

...where $\mathrm{N}_{\mathrm{i}, \mathrm{t}}$ - number of roots defined by the model and $\mathrm{N}_{\mathrm{i}, \mathrm{m}}$ - number of measured roots.

The increase in shear strength of the soil reinforced with roots was determined using a step-strain bundle model modified by applying the Weibull survival function (RBMw) [14]. In this model, the basic tensile strength and strain relationships are described by the following formulas:

$$
\begin{gathered}
L(\phi)=L_{0} \cdot\left(\frac{\phi}{\phi_{0}}\right)^{\gamma} \\
E(\phi)=E_{0} \cdot\left(\frac{\phi}{\phi_{0}}\right)^{\beta} \cdot r \\
F_{\max }(\phi)=F_{0} \cdot\left(\frac{\phi}{\phi_{0}}\right)^{\xi}
\end{gathered}
$$

...where L - length of the root with a diameter $\phi$; $\mathrm{L}_{0}$ - characteristic length of the root with a diameter $\phi_{0}$; $\phi_{0}$ - diameter of a characteristic root, usually assumed as $\mathrm{d}_{0}=1 \mathrm{~mm}$, in order to obtain a dimensionless ratio in equations (7), (8) and (9); $\mathrm{E}_{(\mathrm{d})}$ - the modulus of elasticity of the root with diameter $\phi ; \mathrm{E}_{0}-$ the reference value of the modulus of elasticity of the root with diameter $\phi_{0} ; \mathrm{r}-$ dimensionless coefficient introduced in order to take into account the effect of root tortuosity on its tensile behaviour (assumed as $\mathrm{r}=0.4$ ); $\mathrm{F}_{\max }$ - maximum breaking force; $\mathrm{F}_{0}$ - empirical characteristic force breaking the root with a diameter $\phi_{0}, \gamma, \beta$; and $\xi$ - powerlaw exponents.

In this model, the maximum tensile force transmitted through the root system is a derivative of its displacement and the values of tensile forces mobilized in the individual roots:

$$
F_{\text {tot }}(\Delta x)=\sum_{i=1}^{N} F\left(\phi_{i}, \Delta x\right) \cdot S\left(\Delta x_{i}^{*}\right)
$$

...where $\Delta \mathrm{x}$ - root displacement and $\mathrm{F}\left(\phi_{\mathrm{i}}, \Delta \mathrm{x}\right)$ - the value of the mobilized force stretching the root at displacement $\Delta \mathrm{x}$, calculated from the formula:

$$
F\left(\phi_{i}, \Delta x\right)=\frac{r \cdot \pi \cdot E_{0} \cdot \Delta x}{4 \cdot L_{0}} \cdot \phi_{i}^{2+\beta-\gamma}
$$

$\mathrm{S}\left(\Delta \mathrm{x}_{\mathrm{i}}^{*}\right)-$ survival function:

$$
S\left(\Delta x^{*}\right)=\exp \left[-\left(\frac{\Delta x^{*}}{\lambda}\right)^{\omega}\right]
$$

...where $\Delta \mathrm{x}^{*}$ - normalized displacement.

The values of parameters $\mathrm{E}_{0}, \beta, \mathrm{F}_{0}$ and $\xi$ were determined on the basis of tensile strength tests carried out in a Hounsfield tensile test machine at a deformation rate of $10 \mathrm{~mm} \mathrm{~min}^{-1}$. Directly before the test, root samples of at least $20 \mathrm{~cm}$ long were immersed in water for 12 hours for saturation. Before the test, the root diameter was measured in its middle part. Values of $\mathrm{L}_{0}$ and $\gamma$ were taken from the data provided in the work of Schwarz et al. [8]. The values of survival function parameters $\omega$ and $\lambda$ were determined on the basis of the tensile strength test results according to the procedure described in the work of Schwarz et al. [14].

The increase in shear strength of root-reinforced soil was defined as the ratio of the maximum tensile force to the surface area of the open pit section $\left(1 \mathrm{~m}^{2}\right)$, and the calculations took into account the roots with diameters from 1 to $10 \mathrm{~mm}$, after Bischetti et al. [24], who assume that roots with diameters above $10 \mathrm{~mm}$ do not meet the criterion of the Wu-Waldron model.

Statistical analysis of the results of root measurements consist in determining the significance of differences between the number of roots and the distance from the tree as well as tree species. For this purpose, the non-parametric U Mann-Whitney test was used. When comparing the tensile strength values of the roots of the studied species, the covariance analysis (ANCOVA) was used at the significance level $\alpha=0.01$, where the dependent variable was the breaking force, the qualitative factor was the tree species, and the covariate - the diameter of its roots. Before the calculations, in order to obtain a normal distribution, the data were logarithmised. 


\section{Research Results and their Analysis}

\section{Distribution of Roots in the Soil}

Fig. 1 presents the averaged results of measurements of the number of roots of the examined tree species. In the case of both species, the largest number of roots was inventoried in the subsurface soil layer to a depth of $0.1 \mathrm{~m}$, and this number decreased to a depth of 0.45 to $0.65 \mathrm{~m}$, and then increased. This vertical distribution of roots was associated with the presence of a compacted layer of soil with a moisture content higher than the moisture of the surface layer, which caused the roots to grow horizontally, as confirmed by Coppin and Richards [25]. It should be noted that the predominant part of the roots occurred to a depth of $0.5 \mathrm{~m}$ and in the case of black locust, it was $68.0 \% \pm 5.6 \%$ and $69.4 \% \pm 11.1 \%$ in the case of black poplar, which is comparable to the results of the Cislaghi et al. [26], while higher values are given by Stokes et al. [27]. It should be seen, however, that the substrate of the studied tree species were lowdensity soils (including sandy ones), which is a factor favouring the penetration of roots deep into the soil [28].

The results of the measurements showed that black locust is characterized by a greater number of roots, and black poplar roots achieve larger diameters. In the case of black locust, the number of roots in the trenches was on average 57 (from 35 to 72), and of black poplar
- 36 (from 14 to 81 ). Whereas the maximum diameter of black locust roots was $18.1 \mathrm{~mm}$, and of black poplar was $33.3 \mathrm{~mm}$. In the case of black locust, the number of roots inventoried at a distance of $0.5 \mathrm{~m}$ from the trunk was on average 66 , and at a distance of $1.0 \mathrm{~m}-47$ roots. In contrast, in the case of black poplar, the average number of roots in both distances was very similar and amounted to 36. Statistical analysis showed that the number of black locust roots inventoried at a distance of $0.5 \mathrm{~m}$ from the trunk was significantly higher than of the black poplar $(\mathrm{p}=0.001)$, while at a distance of $1.0 \mathrm{~m}$ from the trunk the number of roots did not differ statistically between the species $(\mathrm{p}=0.133)$. The results of the statistical calculations also did not show the influence of the distance of the trench from the trunk on the measured number of roots (for the black locust $\mathrm{p}=0.059$, and for the black poplar $\mathrm{p}=0.829$ ).

The values of the root area ratio (RAR) of black locust amounted to an average of $0.108 \%$ and $0.054 \%$ at a distance of 0.5 and $1.0 \mathrm{~m}$ from the trunk, respectively. In the case of black poplar, the average value of RAR at a distance of $0.5 \mathrm{~m}$ from the tree was $0.225 \%$, and at a distance of $1.0 \mathrm{~m}, 0.067 \%$. The study was carried out on the same plot [18], but for two years younger trees of these species showed that the average RAR value for the black locust was $0.03 \%$, and for the black poplar $0.045 \%$, where the measurements included roots smaller than $10 \mathrm{~mm}$. Taking into account a similar range of a)

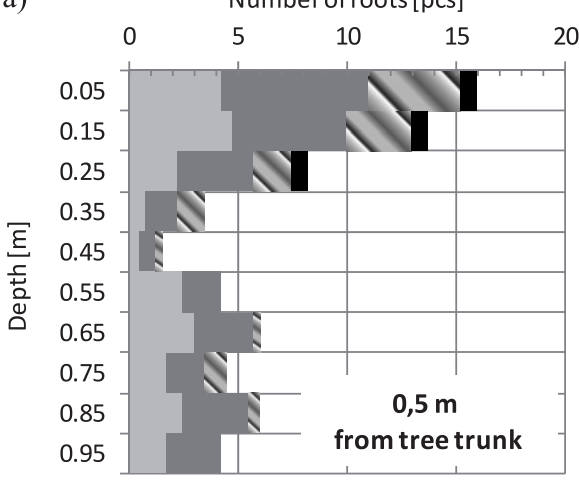

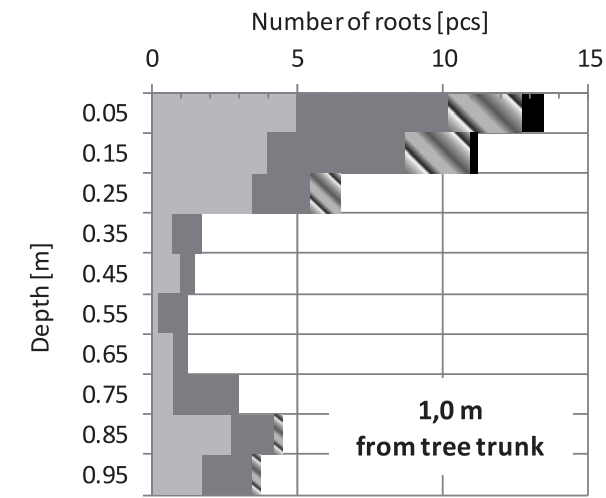

$1-2 \mathrm{~mm} \quad 2-5 \mathrm{~mm} \times 5-10 \mathrm{~mm} \quad>10 \mathrm{~mm}$

b)

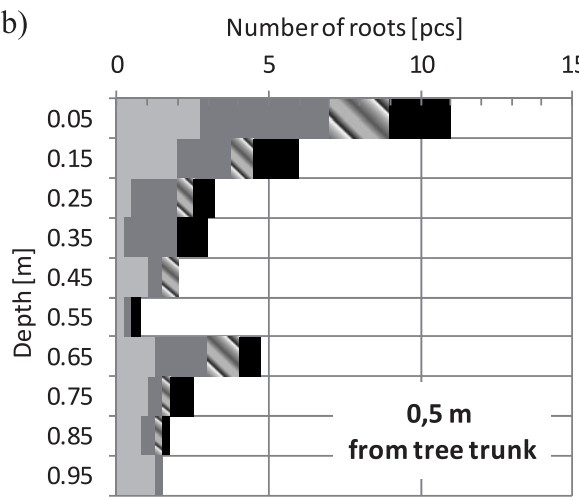

15

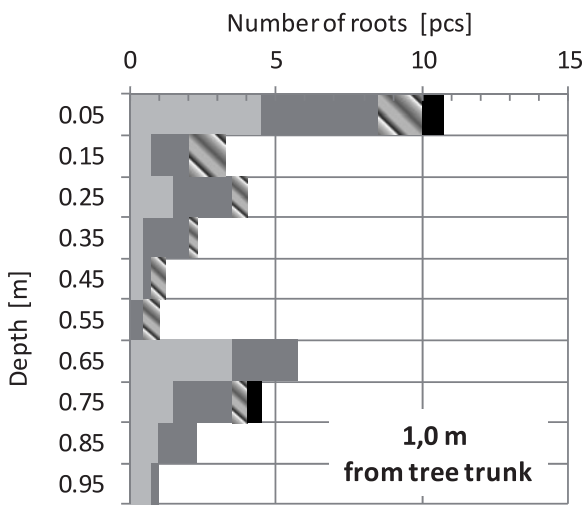

$\square-2 \mathrm{~mm} \square 2-5 \mathrm{~mm} \mathbb{N} 5-10 \mathrm{~mm} \square>10 \mathrm{~mm}$

Fig. 1. Average root density classified in four diameters at different distances from the tree trunk: a) black locust, b) black poplar. 
Table 2. Parameters of root distribution model estimated for the analysed species.

\begin{tabular}{|c|c|c|}
\hline Parameters of RDM & Black locust & Black poplar \\
\hline$\mu$ [roots $\left.\cdot \mathrm{m}^{-2}\right]$ & 87680 & 52726 \\
\hline $\mathrm{a}_{0}[-]$ & 43 & 45 \\
\hline$\eta[-]$ & 250 & 125 \\
\hline$v[-]$ & -1.14 & -1.10 \\
\hline $\mathrm{EV}[\%]$ & 10.03 & 9.49 \\
\hline
\end{tabular}

root diameters as in the studies of Zydron et al. [18], the RAR value for black locust was $0.062 \%$, and for black poplar $0.033 \%$. A smaller value of the root area ratio of black poplar roots may have resulted from other diameters of the root collar of the trees and the greater depth of the excavations.

Based on the measurements of the number and diameter of the roots, the parameters of the modified root distribution model in the soil were estimated (Table 2). The values of the $\mathrm{a}_{0}$ parameter indicate
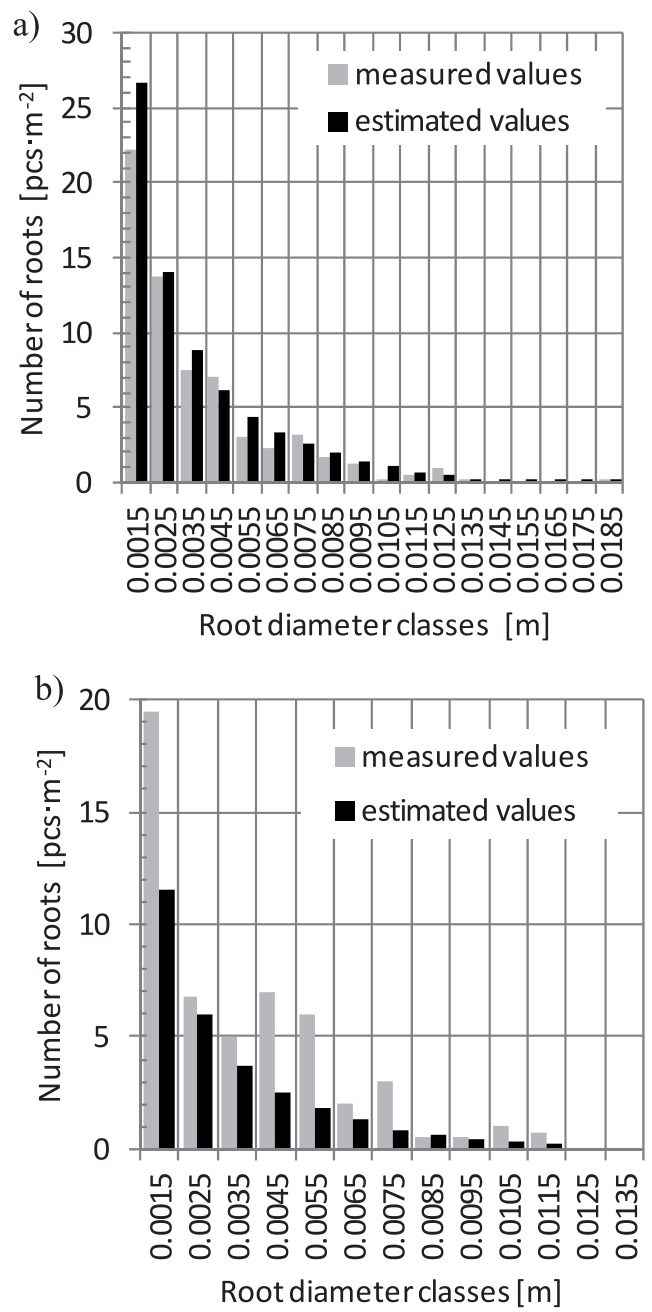

Fig. 2. Measured and estimated root distribution in profiles $0,5 \mathrm{~m}$ a) and 1,0 $\mathrm{m} \mathrm{b}$ ) away from the trunk of black locust. that the horizontal root range is more than 40 times larger than the diameter of the root collar, which is a high value in relation to the value of this parameter determined for Norway spruce [8, 29] or for Jatropha curcas [13]. On the other hand, the results of Kalliokoski et al. [30] and Day et al. [31] indicate that the ratio of the radial extension of the tree root system to the diameter of the root collar exceeds the value of 40, especially in the case of trees with a small value of DBH. For 1- and 2-year-old Veronese poplar seedlings, Schwarz et al. [32] obtained values of the $a_{0}$ parameter in the range of 74-88. For silver birch, Norway spruce and Scots pine with a DBH diameter of about $0.08 \mathrm{~m}$ Kalliokoski et al. [30] observed that, in extreme cases, the root system extension exceeded $5 \mathrm{~m}$ and was close to the height of the trees.

Comparing the results of root number calculations using the RDM model and measured directly in the field is shown in Figs 2 and 3. It can be noticed that for both tree species, the number of the calculated roots at a distance of $0.5 \mathrm{~m}$ from trunks is greater than the number of the inventoried roots. At a distance of $1.0 \mathrm{~m}$ from the trunk, an inverse relationship was found,
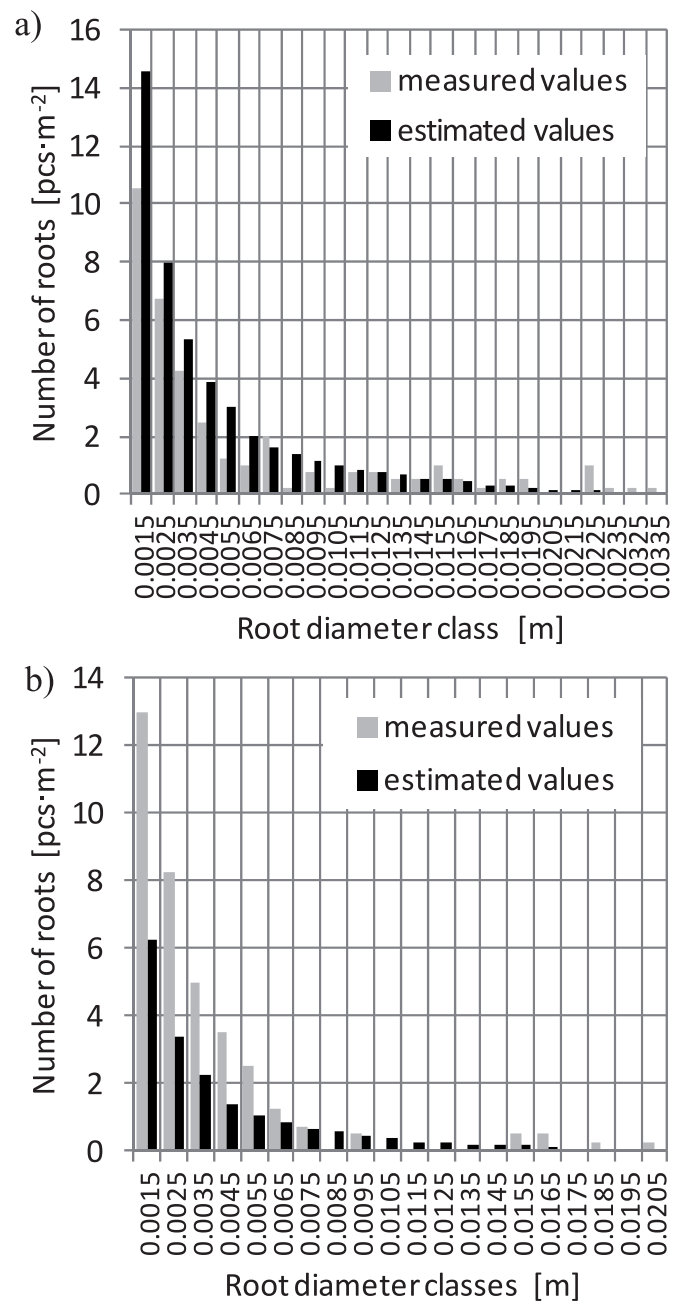

Fig. 3. Measured and estimated root distribution in profiles $0,5 \mathrm{~m}$ a) and 1,0 $\mathrm{m} \mathrm{b}$ ) away from the trunk of black poplar. 
which should be considered as a result safe from the point of view of the assessment of root impact on soil reinforcement. Analyzing the obtained values of the determination coefficient (Fig. 4), it can be concluded that the adjustment of the calculated data to empirical values in the case of black poplar can be considered weak, yet satisfactory in the case of black locust. The total roots number estimation error determined using the model was $10.0 \%$ for black locust and $9.5 \%$ for black poplar, and its greater value for black locust was due to the greater number of roots. The results of other works [9, 13, 26, 29] also indicate that, especially for small roots, the use of the RDM model gives large discrepancies between the number of estimated and measured roots. These discrepancies are highly related to the variability of plant matter [among others 24, $30]$, which is particularly large for young plants [30, 33], which means that it is not possible to show the significance of the differences of comparable root system parameters with statistical methods.

Based on the estimation of the RDM model parameters, the values of the root area ratio in the profile were calculated and compared with the measurement
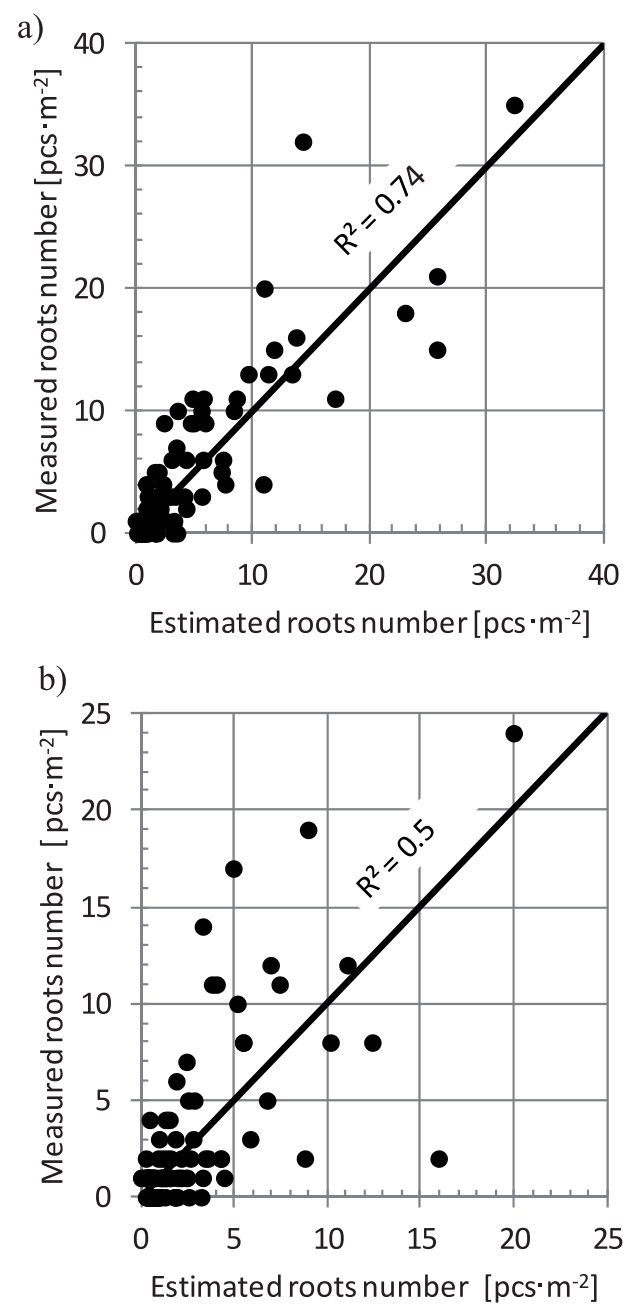

Fig. 4. Comparison of measured and estimated root numbers: a) black locust, b) black poplar.

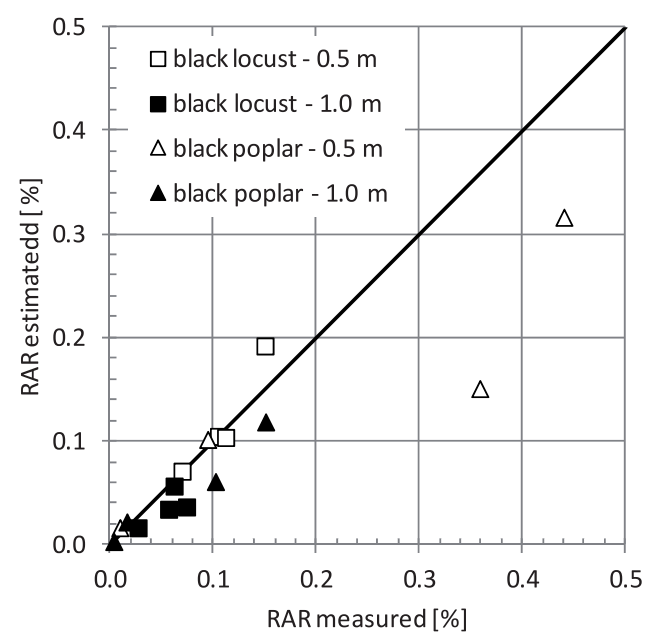

Fig. 5. Comparison of measured and estimated values of root area ratios.

results. The results of this analysis (Fig. 5) indicate that in most of the considered cases, the calculated RAR values are similar or slightly undervalued in relation to the measured values of this parameter, which should be regarded as safe from the point of view of the use of these data for engineering purposes.

\section{Tensile Strength}

Fig. 6 shows the results of the tensile strength tests. In general, it can be concluded that the values of breaking force obtained from the measurements were strongly correlated with the diameter. It is noticeable that the black locust roots were characterized by slightly higher values of breaking force, whereas the difference was not significant from the statistical point of view $(\mathrm{F}(1.129)=1.27, \mathrm{p}=0.26)$.

On the basis of the magnitude of deformation recorded at the root break, the other parameters of the RBMw model were also determined (Table 3). These data indicate that the roots of black poplar have a substantially higher rigidity than those of black locust. The value of the modulus of elasticity determined for black locust is close to the value of the modulus of elasticity specified for this species by Ji et al. [34] or the value of the Norway spruce modulus given in the work of Schwarz et al. [14]. In turn, the value of the modulus obtained for black poplar corresponds to the value of this parameter given in the work of Boldrin et al. [35] for common gorse (Ulex europaeus L.) shrubs or defined for Douglas-fir (Pseudotsuga menziesii) by Commandeur and Pyles [36].

It should be noted that the value of the parameter $\omega$ of the Weibull survival function (Equation (13)) developed for black locust is relatively high and indicates a relatively small variability in the strength of roots of this species (Fig. 7) in relation to the test results. For comparison, the values of this parameter presented in the works of Cislaghi et al. [26], Giadrossich et al. 

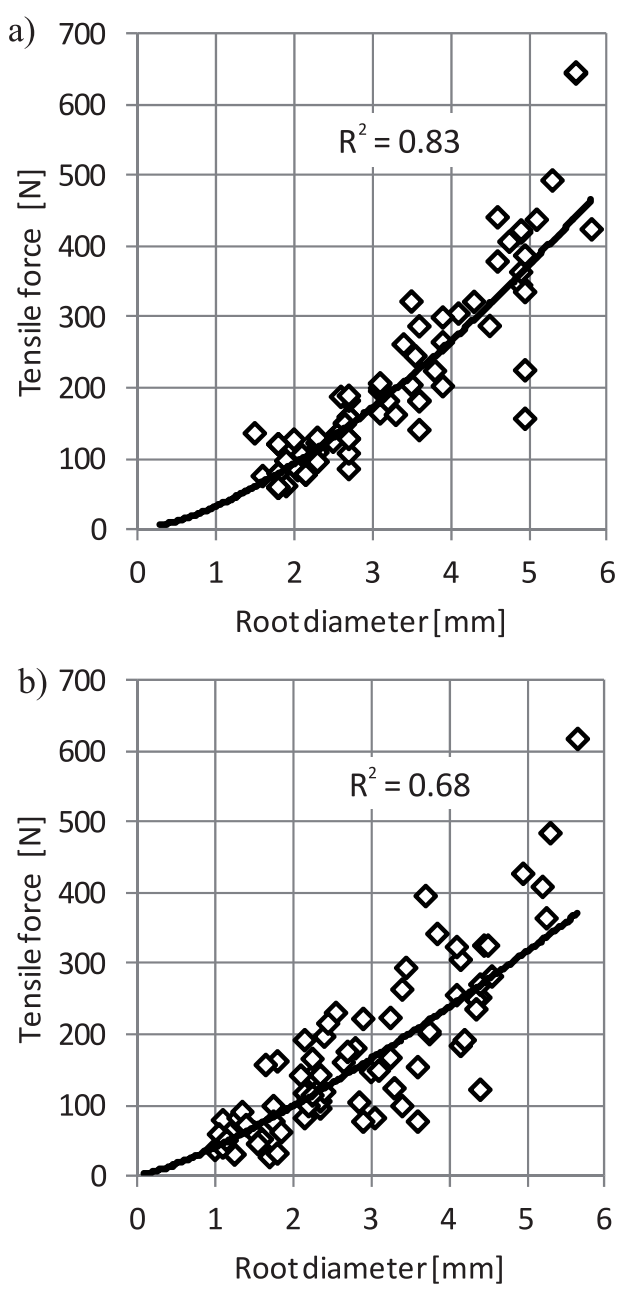

Fig. 6. Tensile force versus diameter of black locust a) and black poplar b).

[13], Schwarz et al. [14], and Vergani et al. [29] are in the range from 1.7 to 6.4 .

\section{Root Cohesion}

On the basis of the results of measurements of the number of roots in the soil profile and their tensile strength, we made calculations of the value of root cohesion $\left(\mathrm{c}_{\mathrm{r}}\right)$. The calculations were performed by two

Table 3. Parameters of root bundle model considering Weibull survival function.

\begin{tabular}{|c|c|c|}
\hline Parameters of RBMw & Black locust & Black poplar \\
\hline $\mathrm{F}_{0}[\mathrm{~N}]$ & 32.4 & 40.6 \\
\hline$\xi[-]$ & 1.52 & 1.28 \\
\hline $\mathrm{E}_{0}[\mathrm{MPa}]$ & 271.4 & 474.4 \\
\hline$\beta[-]$ & -0.46 & -0.27 \\
\hline$\lambda[-]$ & 1.08 & 1.18 \\
\hline$\omega$ & 6.04 & 2.09 \\
\hline
\end{tabular}
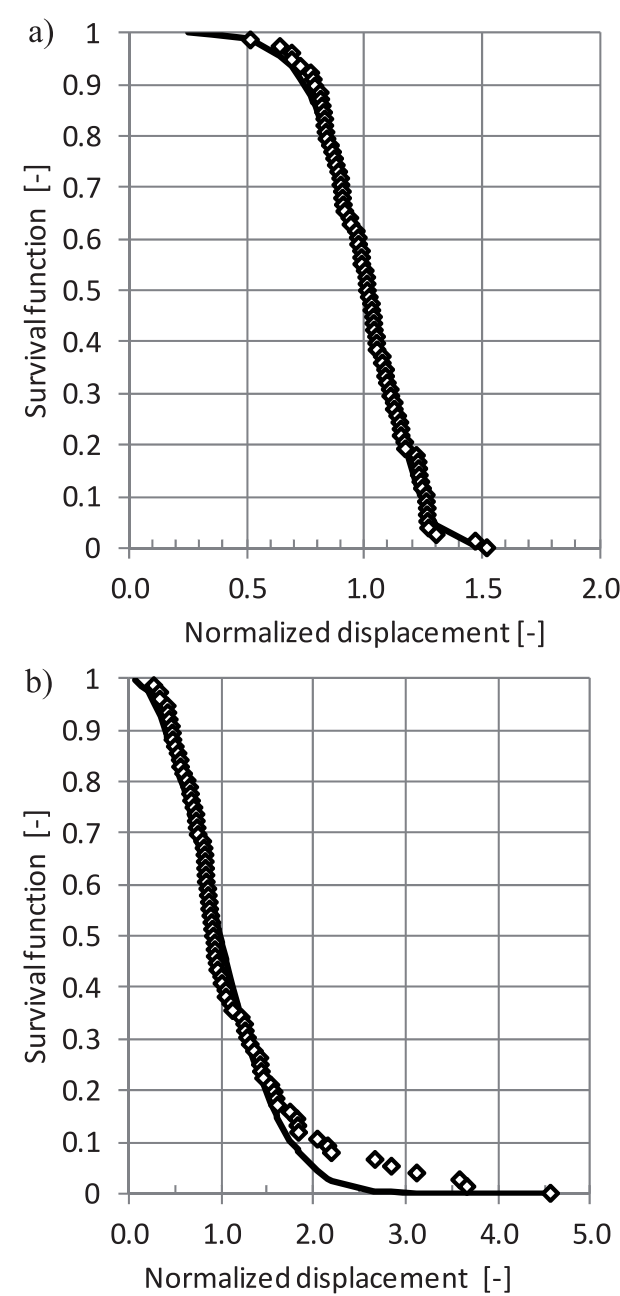

Fig. 7. Survival function of black locust a) and black poplar b) determined for tensile strength test data.

methods. In the first method, the values of $c_{r}$ were calculated based on the results of direct measurements of diameters and number of roots. The second method consisted in using the parameters of the RDM model, for which the number of roots in individual classes of diameters was calculated depending on the diameter at the base of the root collar. It can be noted that the root effect on soil reinforcement significantly decreases with the distance from the trunk, which is consistent with the results of other works [13, 26, 31] and virtually disappears at a distance of $3 \mathrm{~m}$. It should be emphasized that the earlier calculations (RDM model) showed that the root range around the tree was a multiple of the root collar diameter and was 43 and 45 for black locust and black poplar, respectively. Assuming the diameter of the root collar $0.1 \mathrm{~m}$, the theoretical root range should be 4.3-4.5 $\mathrm{m}$ from trees. The calculations of $\mathrm{c}_{\mathrm{r}}$ indicate that the effect of soil strengthening (assuming conventionally the value of $c_{r} \geq 2.0 \mathrm{kPa}$ ) is limited to a distance of 1.0 to $1.2 \mathrm{~m}$, depending on the species, and disappears almost completely at a distance of $3 \mathrm{~m}$.

The results of calculations of the shear strength increase (Fig. 8) based on the direct measurements 
indicate that in the case of black locust they fall within the range of the simulated values of this parameter. In turn, a slightly larger discrepancy between the simulation results and the results of the direct tests was obtained for black poplar. The values of the shear strength increased as determined on the basis of the root measurements in the profile not being large and amounting to a maximum of $9.3 \mathrm{kPa}$ for black locust and $6.4 \mathrm{kPa}$ for black poplar. This agrees with the results of research on root systems of trees occurring near riverbeds [37], or the results of backward mass movements analysis in wooded areas [38-39].

Black locust is commonly regarded as a species that effectively strengthens the soil and also prevents erosion [40]. The results of the research on the root system of young black locusts presented in $\mathrm{Ji}$ et al. [34] indicate that this species is characterized by high values of parameter $c_{r}$, which at a distance of $0.25-0.50 \mathrm{~m}$ from the trunk is usually above $20 \mathrm{kPa}$, and in extreme cases exceeds the value of $100 \mathrm{kPa}$. Using the RBM calculation model, which does not take into account survival function values, these authors obtained on average a $40 \mathrm{kPa}$ increase in the soil shear strength
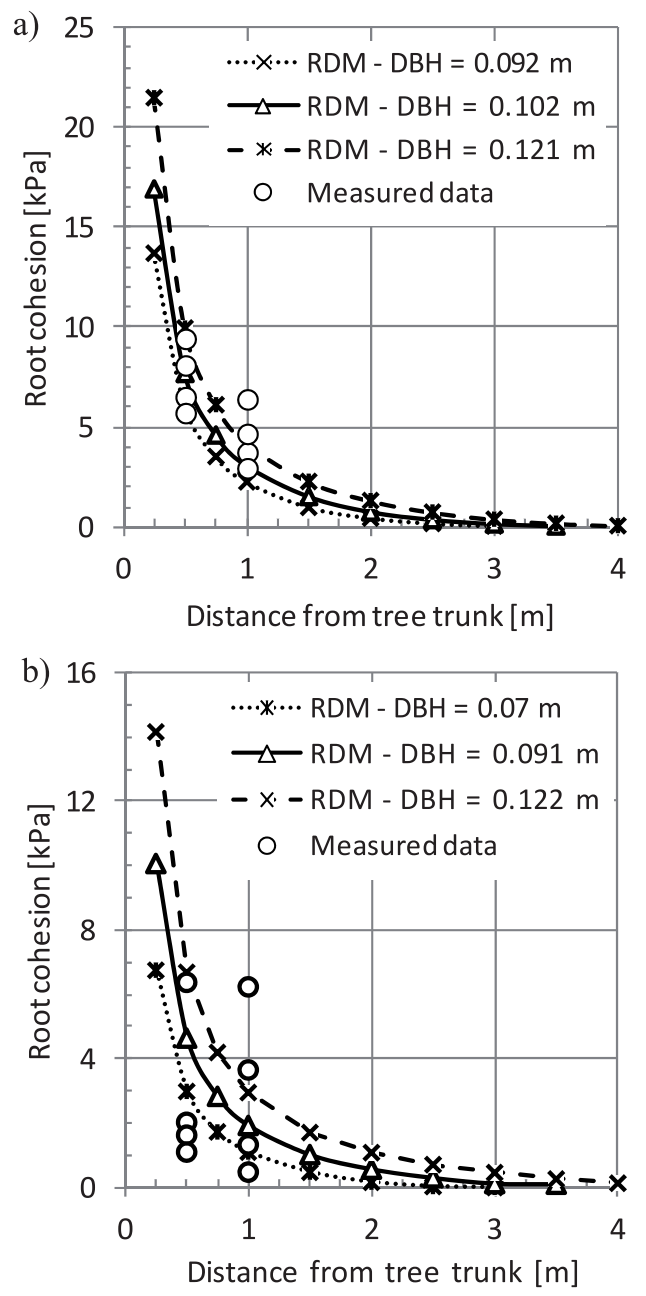

Fig. 8. Root cohesion distribution of black locust a) and black poplar b) using theoretical root distribution and measured data. in the profile. However, it should be emphasized that the authors conducted the research for older trees with a measurement range limited to a depth of $0.5 \mathrm{~m}$ and to small distances from trunks $(0.25$ and $0.5 \mathrm{~m})$, and the obtained values of tensile strength were greater than those obtained in this work. Information on the effect of the root system of poplar plants on soil reinforcement can be found in the work of Schwarz et al. [32], in which the method of estimating the value of root cohesion was the same as in the present research. The authors of this work obtained, for the "Veronese" poplars with a diameter at breast height of $0.15 \mathrm{~m}$ at a distance of about $1 \mathrm{~m}$ from the trunk, the increase in shear strength of the soil by approximately $12 \mathrm{kPa}$. Taking into account that the diameter of the root collar of the studied black poplar was on average $0.09 \mathrm{~m}$, it can be admitted that the obtained results do not differ much from the results of Schwarz et al. [32].

The calculations carried out and their analysis showed that the root effect of the tree species concerned was limited to about $1 \mathrm{~m}$ from the trunk. Therefore, in order to effectively reinforce the soil, consideration should be given to planting the analyzed species with
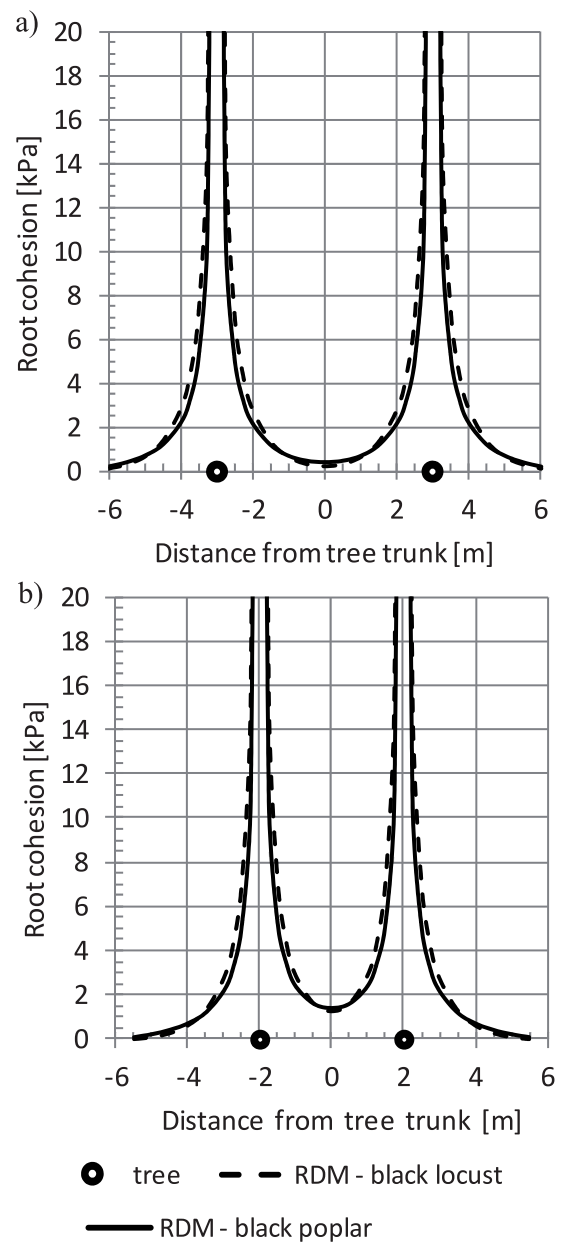

Fig. 9. Increase of soil shear strength (root cohesion) of analyzed tree species assuming $\mathrm{DBH}=0.1 \mathrm{~m}$ : a) spacing of trees $6,0 \mathrm{~m}, \mathrm{~b}$ ) spacing of trees $4,0 \mathrm{~m}$. 
the appropriate spacing. Fig. 9 presents the results of calculations of strengthening the soil at two spacings of the analyzed tree species. The calculations show that at the spacing of $6 \mathrm{~m}$ (Fig. 9a) the value of root cohesion in the middle of the spacing is close to zero, while at the spacing of $4 \mathrm{~m}$ it is almost $2 \mathrm{kPa}$, and thus it can be considered significant, especially if the substrate consists of soils of low cohesion. For comparison, studies of Cislaghi et al. [26] showed that the effective spacing of grapes is $2.5 \mathrm{~m}$ maximum, while Norway spruce with a diameter at a breast height of $0.3 \mathrm{~m}$ is around $5 \mathrm{~m}$.

\section{Conclusions}

The results of the root system measurements of the studied tree species at distances of 0.5 and $1.0 \mathrm{~m}$ from their trunks showed that black locust is characterized by a greater number of roots, while black poplar roots are thicker, which makes the relative surface of its roots greater. It was found that the values of root area ratio for both species were very diverse, with the highest values of this parameter occurring in the surface part of the soil profile to a depth of 0.2 $\mathrm{m}$, and over $60 \%$ of the roots occurred to a depth of $0.5 \mathrm{~m}$. The measurements confirmed that the density of the root system of the trees decreased with the increase in distance from the trunk. The calibration of the RDM model, based on the results of measurements, indicated that the radial extension of the root system and changes in its density were similar, which may be related to the young age of the studied species.

On the basis of the tensile strength test results, we found that the values of the force breaking the black locust and black poplar roots were strongly related to their diameter, but there were no significant differences of this parameter between the tested species. The research also showed that black locust roots were characterized by greater elasticity and variability in strength and strain characteristics than black poplar roots.

Calculations of the shear strength increase using a modified bundle model (RBMw) taking into account the deformation of the root system showed that the maximum value of this parameter averaged in the soil profile to a depth of $1.0 \mathrm{~m}$ was for black locust 9.4 and $6.4 \mathrm{kPa}$, and for black poplar 6.4 and $6.2 \mathrm{kPa}$, respectively, at distances of 0.5 and $1.0 \mathrm{~m}$ from the trunk. These values are in large part consistent with the values of the shear strength increase given in the literature for forested areas.

Analysis of the results of calculations of the root system parameters of the examined tree species (number of roots, root area ratio) estimated using the RDM model or the results of calculations of the shear strength increase values using the integrated RDM and RBMw models indicate that they usually give lower values than those obtained from direct measurements, so these results appear to be safe from the point of view of engineering applications. This claim, however, requires confirmation in further research. The disadvantage of the model used is the assumption that the root system is symmetrical, which is questionable in the case of inclined surfaces, where the state of stress causes asymmetry of root systems of trees [41]. Therefore, future work on the RDM model should focus on the possibility of mapping root systems in situations of uneven environmental factors such as inclination and shape of the slope, and its insolation or dominant wind directions.

\section{Acknowledgements}

Our research was supported by the Ministry of Science and Higher Education, Republic of Poland (DS3322/KIWiG/2018).

\section{Conflict of Interest}

The authors declare no conflict of interest.

\section{References}

1. RAHARDJO H., SATYANAGA A., LEONG E.C., SANTOSO V.A., NG Y.S. Performance of an intrumented slope covered with shrubs and deep-rooted grass. Soils and Foundations, 54 (3), 417, 2014.

2. WANG X., ZHANG W., WANG Z., LIU X., WANG S. Soil Moisture Status under Deep-Rooted and ShallowRooted Vegetation in the Semiarid Area of Loess Plateau in China. Pol. J. Environ. Stud., 23 (2), 511, 2014.

3. GARG A., COO J.L., NG C.W.W. Field study on influence of root characteristics on soil suction distribution in slopes vegetated with Cynodon dactylon and Schefflera heptaphylla. Earth Surface Processes and Landforms, 40, 1631, 2015.

4. GENET M., STOKES A., FOUCAUD T., NORRIS J.E. The influence of plant diversity on slope stability in a moist evergreen deciduous forest. Ecological Engineering, 36, 265, 2010.

5. SCHMIDT K.M., ROERING J.J., STOCK J.D., DIETRICH W.E., MONTGOMERY D.R., SCHAUB T. The variability of root cohesion as an influence on shallow landslide susceptibility in the Oregon Coast Range, Canadian Geotechnical Journal, 38, 995, 2001.

6. ROERING J.J., SCHMIDT K.M., STOCK J.D., DIETRICH W.E., MONTGOMERY D.R. Shallow landsliding, root reinforcement, and the spatial distribution of trees in the Oregon Coast Range. Canadian Geotechnical Journal, 40, 237, 2003.

7. SCHWARZ M., LEHMAN P., OR D. Quantifying lateral root reinforcement in steep slopes - from a bundle of roots to tree stands. Earth Surface Processes and Landforms, 35, 354, 2010.

8. SCHWARZ M. COHEN D., OR D. Spatial characterization of root reinforcement at stand scale: Theory and case study. Geomorphology, 171-172, 190, 2012. 
9. SCHWARZ M., THORMANN J-J., ZÜRCHER K., FELLER K. Quantifying root reinforcement in protection forests: implications for slope stability and forest management. $12^{\text {th }}$ Congress INTERPRAEVENT $2012-$ Grenoble/France, 791, 2012.

10. WU T.H. Investigation on landslides on Prince of Wales Island, Alaska. Geotech engineering report. No 5, Dpt. of Civil Eng., Ohio State Univ., Columbus, USA, 1976.

11. WALDRON L.J. The shear stress resistance of rootpermeated homogeneous and stratified soil. Soil Sci. Soc. Am. Pro., 41, 843, 1977.

12. SAKALS M.E., SIDLE R.C. A spatial and temporal model of root cohesion in forest soils. Can. J. For. Res. 34, 950, 2004.

13. GIADROSSICH F., COHEN D., SCHWARZ M., SEDDAIU G., CONTRAN N., LUBINO M., VALDESRODRIGUEZ O.A., NIEDDA M. Modeling bioengineering traits of Jatropha curcas L. Ecological Engineering, 89, 40, 2016.

14. SCHWARZ M., GIADROSSICH F., COHEN D. Modeling root reinforcement using a root-failureWeibull survival function. Hydrol. Earth Syst. Sci., 17, 4367, 2013.

15. KODA E., PACHUTA K., OSINSKI P. Potential of Plant Applications in the Initial Stage of the Landfill Reclamation Process. Pol. J. Environ. Stud., 22 (6), 1731, 2013.

16. GENET M., KOKUTSE N., STOKES A., FOURCAUD T., CAI X., JI J., MICKOVSKI S. Root reinforcement in plantations of Cryptomeria japonica D. Don: effect of tree age and stand structure on slope stability. Forest Ecology and Management, 256, 1517, 2008.

17. BISCHETTI G.B., CHIARADIA E.A., D'AGOSTINO V., SIMONATO T. Quantifying the effect of brush layering on slope stability. Ecological Engineering, 36, 258, 2010.

18. ZYDROŃ T., BIENIAS B., GRUCHOT A. Wpływ systemu korzeniowego topoli czarnej i robinii akacjowej na wytrzymałość na ścinanie gruntów. (Influence of the root system of black poplar and black locust on the shear strength of soils.) Rocznik Ochrona Środowiska (Annual Set The Environment Protection), 18, 772, 2016.

19. PN-EN ISO 17892-4:2009. Geotechnical investigation and testing - Laboratory testing of soil - Part 4: Determination of particle size distribution. PKN.

20. PN-EN ISO 14688-2:2009. Geotechnical investigation and testing - Identification and classification of soil - Part 2: Principles for a classification. PKN.

21. OSTROWSKA A., GAWLIŃSKI S., SZCZUBIAŁKA Z. Methods of analysis and assessment of soil properties and plant, first ed., Institute of Environmental Protection, 333, 1991 [In Polish].

22. BARAN A., CZECH T., WIECZOREK J. Chemical properties and toxicity of soils contaminated by mining activity. Ecotoxicology, 2 (7), 1234, 2014.

23. VERGANI C., SCHWARZ M., SOLDATI M., CORDA A., GIADROSSICH F., CHIARADIA E.A., MORANDO P., BASSANELLI C.. Root reinforcement dynamics in subalpine spruce forests following timber harvest: a case study in Canton Schwyz, Switzerland. Catena, 143, 275, 2016.

24. BISCHETTI G.B., CHIARADIA E.A., EPIS T., MORLOTTI E. Root cohesion of forest species in the Italian Alps. Plant and Soil, 324, 71, 2009.

25. COPPIN N.J., RICHARDS I.G. Use of vegetation in civil engineering. Butterworth, London, 1990.
26. CISLAGHI A., BORDONI M., MEISINA C., BISCHETTI G.B. Soil reinforcement provided by the root system of grapevines: Quantification and spatial variability. Ecol. Eng. 109 (B), 169, 2017.

27. STOKES A., ATGER C., BENGOUGH A.G., FOURCAUD T., SIDLE R.C. Desirable plant root traits for protecting natural and engineered slopes against landslides. Plant Soil 324 (1-2), 1, 2009.

28. TOMANEK J. Botanika leśna. Państwowe Wydawnictwo Rolnicze i Leśne, Warszawa. (Forest botany. National Agricultural and Forest Publishing, Warsaw.), 1997.

29. VERGANI C., SCHWARZ M., COHEN D., THORMANN J.J., BISCHETII G.B. Effects of root tensile force and diameter distribution variability on root reinforcement in the Swiss and Italian Alps. Can. J. For. Res. 44, 1426, 2014.

30. KALLIOKOSKI T., NYGREN P., SIEVÄNEN R.. Coarse root architecture of boreal tree species growing in mixed stands. Silva Fennica, 42 (2), 189, 2008.

31. DAY S.D., WISEMAN P.E., DICKINSON S.B., HARRIS J.R. Contemporary concepts of root system architecture of urban trees. Arboriculture\&Urban Forestry, 36 (4), 149, 2010.

32. SCHWARZ M., PHILIPS C., MARDEN M., McIVOR I.R., DOUGLAS G.B., WATSON A. Modelling of root reinforcement and erosion control by 'Veronese' poplar on pastoral hill country in New Zealand. New Zealand Journal of Forestry Science, 46, 4, 2016.

33. BURYLO M., HUDEK C., REY F. Soil reinforcement by the roots of six dominant species on eroded mountainous marly slopes (Southern Alps, France). Catena, 84, 70, 2011.

34. JI J., KOKUTSE N., GENET M., FOURCAUD T., ZHANG $Z$. Effect of spatial variation of tree root characteristics on slope stability. A case study on Black Locust (Robinia pseudoacacia) and Arborvitae (Platycladus orientalis) stands on the Loess Plateau, China. Catena, 92, 139, 2012.

35. BOLDRIN D., LEUNG A.K., BENGOUGH A.G. Root biomechanical properties during establishment of woody perennials. Ecological Engineering, 109 (B), 196, 2017.

36. COMMANDEUR P.R., PYLES M.R. Modulus of elasticity and tensile strength of Dougla-fir roots. Can. J. For. Res, 21, 48, 1991.

37. SIMON A., COLLISON A.J.C. Quantifying the mechanical and hydrologic effects of riparian vegetatian on streambank stability. Earth Surface Proccesses and Landforms, 27, 527, 2002.

38. BUCHANAN P., SAVIGNY K.W. Factors controlling debris avalanche initiation. Canadian Geotechnical Journal, 27, 659, 1990.

39. BURROUGHS E.R., THOMAS B.R. Declining root strength in Douglas-fir after felling as a factor in slope stability. USDA For. Serv. Res. Pap. INT-1 90, 27 p. Intermt. For. and Range Exp. Stn., Ogden, Utah, 1977.

40. LI Q., LIU G., ZHANG Z., TUO D., MIAO X. Structural Stability and Erodibility of Soil in an Age Sequence of Artificial Robinia pseudoacacia on a Hilly Loess Plateau. Pol. J. Environ. Stud., 25 (4), 1595, 2016.

41. STOKES A., NORRIS J.E., VAN BEEK L.P.H., BOGAARD T., CAMMERAAT E, MICKOVSKI S.B., JENNER A., DI IORIO A., FOURCAUD T. How vegetation reinforces soil on slopes. [W:] Norris J.E., Stokes A., Mickovski S.B., Cammeraat E., van Beek R., Nicoll B.C., Achim A. (red.). Slope Stability and Erosion Control: Ecotechnological Solutions. Springer, 65-118, 2008. 